\title{
POLA PEMBINAAN PRESTASI OLAHRAGA USIA DINI PADA SD NEGERI 2 PERCONTOHAN TIJUE
}

\author{
Amirzan \\ Dosen Prodi Penjaskesrek, FKIP Universitas Jabal Ghafur
}

\begin{abstract}
ABSTRAK
Dukungan seluruh unsur yang terkait dalam pengembangan prestasi siswa di sekolah dipandang sebagai suatu hal yang sangat penting dalam program peningkatan prestasi olahraga usia dini di sekolah, dengan penyelenggaraan pembelajaran PJOKyang berfungsi untuk mengembangkan potensi fisik siswa yang mengarah kepada pembinaan aspek psikomotor, karena semua akan bermuara dan bermanfaat bagi siswa untuk mengembangkan potensi kemampuan berolahraga yang ia miliki. Penelitian yang berjudul Pola Pembinaan Prestasi Olahraga Usia Dini Pada SD Negeri 2 Percontohan Tijue bertujuan untuk mengetahui bagaimana sistem pembinaan prestasi olahraga usia dini di sekolah, dan bagaimana peran guru bidang studi, karyawan dan Kepala Sekolah dalam membina prestasi olahraga di sekolah. Penelitian yang menentukan sampel Kepala Sekolah, wakil kepala sekolah Guru PJOK, Guru Kelas, karyawan dan siswa sebanyak 25 orang.Sedangkan isntrumen penelitian dengan mengedarkan angket.Bedasarkan bukti-bukti yang telah dikumpulkan bahwa Pembinaan prestasi olahraga usia dini di SD Negeri 2 Percontohan Tijue dilaksanakan dengan kegiatan pembinaan yang terprogram, didukung oleh guru PJOK yang memenuhi keriteria kelayakan, mendapat persetujuan dari semua guru kelas yang ada, kegiatan pembinaan dibiayai seluruhnya oleh sekolah dan wali siswa, kepala sekolah membina dengan baik, hasil penelitian membuktikan bahwa pembinaan cabang olahraga telah berjalan sebagai mana mestinya.
\end{abstract}

Kata Kunci : Prestasi, Olahraga, Usia dini

\section{PENDAHULUAN}

Pendidikan Jasmani Olahraga Kesehatan (PJOK) adalah salah satu mata pelajaran yang dikembangkan dengan aspek psikomotor yang lebih dominan,namun pada prinsipnya bertujuan secara umum untuk meningkatkan seluruh komponen yang ada pada diri seseorang, sebagaimana Toha Cholik Mutohir (2002:16) "Pendidikan Jasmani memiliki tujuan yang berbeda dengan pelatihan jasmani seperti halnya dalam olahraga prestasi. Pendidikan jasmani diarahkan pada tujuan secara keseluruhan (multilateral) seperti halnya tujuan pendidikan secara umum". Dengan sasaran pada pengembangan keterampilan melalui aktifitas fisik, dan unsur gerak, yang mempersiapkan diri individu peserta didik lebih siap menghadapi berbagai tuntutan hidup aktif, progresif dan menyenangkan dalam mencapai kehidupan yang lebih baik, yang mementingkan kemampuan perceptual motorik, dan pembinaan keterampilan gerak fundamental, maka untuk menunjang proses pendidikan secara umum dan dibutuhkan suatu pembinaan yang mengarahkan kepada pembinaan aspek keterampilan yang dirancang dengan program pembinaan yang terarah, Terpadu dan berkelanjutan.

Pembinaan dan pengembangan olahraga dikalangan usia sekolah dasar hingga perguruan tinggi secara profesional merupakan hal yang sangat penting, pembinaan keterampilan melalui pembelajaran PJOK, terutama para remaja usia dini yang masih berada pada jenjang pendidikan dengan harapan untuk melahirkan siswa-siswa potensi yang prestasi terutama para siswa yang masih berada pada bangku-bangku sekolah dasar.

Sudah saatnya kita mengadakan program-program Pembibitan olahragawan secara terpadu dan menyeluruh, pemandu bakat harus diperbanyak, dan dibina secara teratur, terus-menerus dan terencana, sehingga dapat mencapai prestasi tinggi. Pembibitan olahragawan harus dimulai dari jenjang yang paling bawah seperti di sekolah-sekolah, maka pembinaan yang terorganisir perlu dilaksanakan dengan baik sehingga akan mudah terjangkau terkait pembinaan prestasi 
kepada seluruh peserta didik yang memiliki potensi prestasi dikemudian hari.

KONI Pusat (1997:7) menjelaskan "Peningkatan prestasi tidak akan tercapai apabila pemassalan dan Pembibitan tidak direncanakan dan diprograrnkan secara terpadu, terarah,berjenjang, dan berkesinambungan". Sehubungan dengan pernyataan di atas bahwa upaya pemasalan olahraga merupakan hal yang sangat penting dilaksanakan, karena tahap ini merupakan tahap yang sangat menentukan untuk menimbulkan gairah prestasi olahraga terutama bagi yang berusia remaja, terutama yang masih berada di bangku-bangku sekolah.

Sekolah merupakan bagian yang berfungsi untuk melaksanakan kegiatan pembelajaran sekolah lebih terarah kepada pembinaan potensi prestasi dikalangan siswa, dengan melaksanakan kurikulum dengan menerapkan program yang terukur Pembinaan bibit-bibit unggul berprestasi dan menjanjikan masa depan prestasi, hal ini memiliki tanggung jawab seluruh komponen bangsa secara berjenjang, yaitu guru PJOK di sekolah memiliki tanggung jawab untuk mengadakan pemasalan, memperkenalkan cabang olahraga tertentu sesuai kurikulum, berfungsi secara objektif dan bertanggung jawab melaksanakan proses pembelajaran dan pelatihan untuk mencapai prestasi yang diharapkan.

Dengan demikian maka dalam kerangka proses pemilihan bibit, pembibitan awal sampai kepada pembinaan prestasi telah tersedia rangkaian kelembagaan yang langsung bertanggung jawab, dan tanggung jawab tertinggi ada pada KONI (Komite Olaharga Nasional Indonesia), sedangkan yang bertanggung jawab paling bawah adalah guru PJOK di sekolah. Dengan demikian pembinaan prestasi di sekolah perlu ditindak lanjuti oleh seluruh personil sekolah terutama melalui kebijakan kepala sekolah, bahkan telah diselenggarak pewrlombaan dan pertandingan antar sekolah ditingkat Kabupatren, Propinsi dan Nasional yang di gelar seperti kegiatan O2SN.

Dukungan kepala sekolah dalam pengembanganpembelajaranPendidikan

Jasmani Olahraga Kesehatan (PJOK) di sekolah dipandang sebagai suatu hal yang sangat penting karena melalui penyelenggaraan pendidikan jasmani dapat mengembangkan potensi Fisik siswa untuk mengembangkan potensi kesegaran jasmani yang bermuara kepada pembinaan kesiapan siswa menjalankan tugas dan kewajibannya di lingkungan masyarakat secara fisik, menjadi dasar pembinaan kemampuan berolahraga yang mengarah kepada upaya pembibitan prestasi olahraga dan menjadi dasar pembinaan di sekolah-sekolah.

Namun bagaimana peran kepala sekolah, guru PJOK, maupun guru bidang studi yang lainnya terkait dalam hal pembibitan dan pembinaan cabang olahraga prestasi di sekolah melalui pembelajaran dan pelatihan untuk mencapai suatu keberhasilan prestasi olahraga di sekolah, apakah mereka sebagai insan yang terkait dalam pembinaan olahraga usia dini tersebut mampu menyediakan alat dan fasilitas olahraga secara lengkap dan memenuhi standar kelayakan untuk digunakan serta memberikan bekal ketrampilan untuk diperagakan saat mengikuti pertandingan maupun perlombaan di segala tingkatan kegiatan yang diselenggarakan, bagaimana dukungan kepala sekolah dalam kegiatan pemassalan olahraga di sekolah, bagaimana program guru PJOK untuk menuju sebuah berhasilan kegiatan pembibitan olahraga serta bagaimana dukungan para guru bidang studi lainnya dan karyawan terhadap pembibitan olahraga di sekolah.

Pembinaan prestasi usia dini di sekolah dilakukan berdasarkan cabang olahraga tertentu yang dikembangkan struktur kurikulum PJOK dan kesehatan di sekolah. Pembinaan cabang olahraga dalam mata pelajaran PJOK dan kesehatan (penjaskes) dalam melaksanakan kurikulum sesuai dengan alokasi waktu yang tersedia di dalam jam pelajaran. Pengembangan pembelajaran penjaskes tersebut berdasarkan program pembelajaran.

Pembinaan prestasi usia dini di sekolah yang menggunakan waktu diluar kurikulum atau kegiatan ekstra kurikuler dengan memanfaatkan waktu sore hari, kegiatan tersebut diadakan latihan pembinaan fisik dan teknik dengan pembinaan teratur yng menggunakan program latihan yang sesuai dengan tujuan prestasi. Pembinaan diarahkan kepada siswa-siswa yang memiliki potensi dan bakat prestasi, dengan kondisi yang unggul dalam daya tahan, kecepatan, dengan kondisi fisik pemain sepakbola yang menjadi dasar pencapaian prestasi sepakbola di sekolah.

Guru PJOK di sekolah berperan membina kondisi fisik siswa dengan kemampuan fisik yang mengarah kepada keunggulan jasmani dalam kapasitas memiliki 
kemampuan kesegaran jasmani yang mampu melaksanakan tugas dengan berhasil.Hal ini sesuai dengan pengertian kesegaran jasmani itu sendiri yaitu sebagaimana Sadoso (1994:19) bahwa "Kesegaran jasmani adalah kemampuan seseorang untuk menunaikan tugas sehari-hari dengan gampang, tanpa merasa lelah yang berlebihan dan masih mempunyai sisa atau cadangan tenaga untuk menikmati waktu senggangnya dan untuk keperluan-keperluan yang mendadak".

Terdapat berbagai kondisi objektif yang dikatakan orang berada dalam keadaan fit kesegaran jasmaninya yaitu yang mempunyai kekuatan, kemampuan dan ketangkasan, kesanggupan dan kreasi, day tahan untuk melakukan Pekerjaan dengan efisien tanpa mengalami kelelahan yang berarti, kalau juga mencapai keadaan yang kurang bertenaga, maka segera akan merasa fit kembali dalam waktu yang tidak terlalu lama, sehingga masih memiliki cadangan energi dan semangat positif dalam memperhatikan fungsinya bagi keluarga dan masyarakat.

Guru PJOK merupakan salah satu unsur yang bertanggung jawab terhadap kelangsungan pembinaan prestasi olahraga di sekolah, peran guru penjaskes sangat penting artinya di dalam melaksanakan proses pembelajaran penjaskes, guru penjaskes, guru penjaskes dapat melaksanakan pembinaan prestasi usia dini di sekolah dengan mendasari menyelenggarakan pemassalan olahraga yang bertahap kepada siswa kemudian membina dengan program yang berkelanjutan yang terarah kepada dasar pembinaan prestasi.

Pembibitan prestasi olahraga di sekolah merupakan bagian dari tugas, peran dan bagian tanggung jawab guru penjaskes di sekolah, guru berperan melaksanakan Pembibitan olahragawan di sekolah, dalam hal ini Mutohir (2002:21) mengemukakan "Idealnya, sesuai dengan pandangan hidup (filsafat) dan konsep pendidikan jasmani yang kita anut, pembinaan olahraga usia dini tiu diarahkan pada pengenalan dan penguasaan ketrampilan dasar suatu cabang olahraga yang dilengkapi dengan pengembangan ketrampilan serta kemampuan fisik yang bersifat umum".

\section{DUKUNGAN PIHAK TERKAIT DALAM PEMBINAAN PRESTASI USIA DINI}

Arismunandar (1972) mengemukakan "Secara rata rata pembinaan dini dimulai pada usia 10 tahun dan dibutuhkan latihan 8 tahun hingga 10 tahun untuk menjadi juara". Kutipan di atas membuktikan bahwa pembinaan seorang atlit membutuhkan waktu yang panjang, dengan melibatkan berbagai unsure pembina, diantaranya adalah :

1) Pihak sekolah (pemerintah), dalam hal ini melibatkan

a. Guru penjaskes.

b. Kepala sekolah.

c. Pemerintah daerah.

2) Pihak keluarga (orang tua).

3) Pihak masyarakat.

Pembinaan prestasi yang membutuhkan waktu latihan antara 8 tahun pembinaan, untuk itu peran guru di sekolah sangat penting artinya dalam membina kesiapan siswa, pembinaan yang dilakukan di bangku sekolah semasa anak dalam kelompok umur usia dini, pada saat siswa masih duduk di bangku sekolah dasar kelas IV, sampai siswa masih sekolah tingkat SLTA, bahkan sampai pada jenjang perguruan tinggi, untuk memenuhi aspek pembinaan tersebut maka keberadaan guru PJOK di sekolah merupakan hal Yang sangat berguna dalam, mengembangkan bakat dan prestasi siswa.

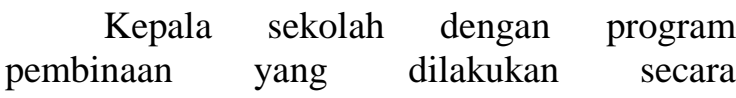
terus $\neg$ menerus dalam memanfaatkan segala sumber daya yang ada, baik sebagai sumber daya siswa yang membawa potensi, pemerintah yang menyediakan berbagai kebutuhan, orang tua dengan peran dan tanggung jawabnya, dan masyarakat dalam, mengontrol kegiatan pembinaan.Dalarn hal ini kepala sekolah menjadi fasilitator pembinaan prestasi sepakbola di sekolah dan dikembangkannya diluar sekolah dengan tujuan prestasi.

Pemerintah daerah mempunyai peran dan tangung jawab yang besar dalam pembinaan prestasi siswa di sekolah dengan berbagai program pembinaan yang dilakukan, pemerintah memiliki posisi yang kuat dalam membina prestasi siswa, karena berbagai keunggulan, diantaranya memiliki power yang police untuk menentukan kebijakan dan program pembinaan berdasarkan kekuatan keunggulannya. Pemerintah dapat menentukan langkah dan menetapkan sikap yang diperlukan untuk pembinaan prestasi, prestasi usia dini berhubungan dengan siswa di sekolah, sedangkan sekolah merupakan aset pemerintah yang perlu dilestarikan oleh seluruh komponen yang ada. 
Bayi yang baru dilahirkan sang ibu laksana selembar kain atau kertas putih yang tidak ternoda oleh suatu coretan apapun, hanya yang membuat mereka berwarna atau bernoda adalah disebabkan karena faktor lingkungan anak itu berada, apakah lingkungan keluarga, lingkungan sekolah/pendidikan ataupun lingkungan masyarakatnya. Sebaliknya ketidak ternodaan anak yang baru dilahirkan itu memiliki potensi rasa, karsa, pikir, intelegensi, kemauan dan lain lain yang bakal berkembang bila dipengaruhi dengan metoda metoda tertentu yang disebut dengan pendidikan.

Pada umumnya orang orang yang mempunyai bakat dan prestasi olahraga tertentu dapat terwarisi kepada anak anaknya, sebagai contoh : seorang ayah yang memiliki bakat dan prestasi sepakbola akan turun bakat dan prestasi sepakbolanya itu kepada salah satu atau lebih anaknya berbakat sepakbola. Cuma perkembangan bakat itu sangat tergantung kepada pembinaan.

Kehadiran peranan orang tua yang memiliki dedikasi yang besar tentu akanberpengaruh dalam membina, mengarahkan, dan mengembangkan potensi yang dimiliki si anak sehingga akan berkembang seiring dengan perkembangan fisiknya. Keluarga merupakan sebuah wadah yang dapat diandalkan untuk membina potensi anak agar dapat dikembangkan menjadi manusia yang bakal berprestasi.

Dukungan orang tua di rumah sangat berpengaruh dan memegang peranan yang sangat penting untuk membina potensi anak baik yang berhubungan dengan pengembangan kepribadian, ketrampilan dan potensi bakat, minat, maupun dalam hubungannya dengan pembinaan ketrampilan, menyediakan waktu yang cukup dan kesempatan yang bermanfaat untuk mengembangkan ketrampilan menguasai teknik yang diperlukan dalam mempelajari cabang olahraga tertentu, mengikuti latihan teratur dengan dukungan moral sebagai motivasi positif sehingga dapat menghasilkan suatu prestasi yang dapat dibanggakan.

Masyarakat besar pengaruhnya dalam membina prestasi sepakbola, sebagai hadirnya penonton dalam satu pertandingan, salah satu sifat penonton adalah jenis penonton objektif yaitu yang menghendaki tersajinya mutu pertandingan yang enak dinikmati. Pertandingan ini menuntut pemainnya untuk menyuguhkan mutu pertandingan yang mendapat support penonton, penonton tipe ini tidak dapat menerima penampilan pemain yang menyajikan penampilan buruk. Kesebelasan yang sanggup menampilkan permainan menarik mendapat dukungan moral penonton terlepas dari menang kalahnya kesebelasan yang tampil, dan menjadi moment berharga dalam menciptakan prestasi sepakbola.

\section{PROSEDUR PENELITIAN}

Penelitian ini merupakan penelitian dengan pendekatan kualitatif. Menurut Moleong (1990) Penelitian kualitati berakar pada latar almiah sebagai keutuhan, mengandalkan manusia sebagai alat penelitian, mamfaat metode kual;itatif menggunakan analisa secara induktif. Penelitian kualitatif lebih mementinhgkan proses daripada hasil.

$$
\text { Menurut Sugino (2007) Dalam }
$$
penelitian kualitatif instrumen utamanya instrumen peneliti sendiri, namun selanjutnya setelah fokus menjadi jelas, maka kemungkinan instrument sederhana menjadi yang diharapkan dapat melengkapi data dan membandingkan dengan data yang telah ditemukan melalui observasi dan wawancara. Peneliti akan terjun sendiri ke lapangan untuk melakukan pengumpulan data, analisa data dan kesimpulan. Sebagaimana yang dikemukakan oleh Nasuytian (1988) dalam Sugiyono (2007) : Dalam kualitatif tidak ada pilihan lain daripada menjadikan manusia sebagai instrument penelitian utama. Alasannya ialah bahwa, segala sesuatunya belum mempunyai bentuk yang pasti. Masalah focus penelitian, prosudur penelitian, hipotesis yang digunakan, bahkan hasil yang diharapkan, itu tidak dapat ditentukan secara pasti dan jelas sebelumnya. Segala sesuatu masih perlu dikembangkan sepanjang penelitian itu. Dalam keadaan yang serba tidak pasti dan tidak jelas, tidak ada $\mathrm{p}$ [ilihan lain dan hanya peneliti itu sendiri alat satu-satunya yang dapat mencapainya. Sehingga yang dijadikan objek atau inpermen dalam penelitian ini adalah Kepala Sekolah, Guru PJOK, Guru Kelas dan Karyawan yang ada SD Negeri 2 Percontohan Tijue.

\section{HASIL PENELITIAN}

Berdasarkan hasil penelitian dari 26 tabel atau soal pada angket hanya tiga table yang mencerminkan bahwa pembinaan olahraga usia dini tidak berjalan sebagai mana mestinya, sedangkan 23 tabel yang lainnya dapat dujadikan sebagai acuan kegiatan pembinaan prestasi olahraga usia dini telah 
berjalan dengan baik, serta didukung oleh bukti-bukti yang telah dikumpulkan, maka dapat dikemukakan bahwa pembinaan prestasi olahraga usia dini di SD Negeri 2 Percontohan Tijuetelah dilaksanakan dengan baik, artinya kegiatan pembinaan yang telah terprogram, didukung oleh guru PJOK yang memenuhi keriteria kelayakan sebagai guru dan pelatih, mendapat persetujuan dari semua guru kelas dan seluruh karyawan yang ada, kegiatan pembinaan dibiayai seluruhnya oleh sekolah dan wali murid, serta kepala sekolah memberikan dukungan sepenuhnya dalam kegiatan pembinaan prestasi program usia dini di sekolah tersebut.

Guru PJOK bersama siswa telah mengawali program pembinaan yang matang dengan kegiatan yang cukup bearti untuk membina prestasi siswa yang diikuti dengan antusiasme tinggi, dukungan alat dan fasilitas yang cukup, termasuk dana transportasi siswa yang memadai, mengapat dukungan orang tua siswa secara baik, penerapan latihan yang berimbang antara fisik dan tehnik, dan dalam situasi menghadapi pertandingan juga diberikan latihan dengan sasaran membina mental agar siap menghadapi lawan, segala kelemahan dalam pertandingan dibahas dengan seksama dan diperbaiki pada latihan berikutnya, pembinaan ini telah menjadi program tetap yang mengarah pada pembinaan prestasi olahraga usia dini secara terus menerus atau berkesinambungan.

\section{KESIMPULAN}

Pembinaan prestasi olahraga usia dini pada SD Negeri 2 Percontohan Tijue telah mengemabangkan program latihan yang teratur pada klub sekolah yang bertujuan utnuk mencapai prestasi olahraga usia dini secara maksimal. Pembinaan didukung oleh seluruh guru kelas, karyawan dan antusiasme siswa, dukungan dana yang cukup, dukungan dan pembinaan kepala sekolah serta bantuan partisipasi orang tua. Guru PJOK bersama siswa mengawali program pembinaan prestasi dengan dukungan alat dan fasilitas yang cukup, pemberian dana transportasi siswa, penerapan latihan fisi, tehnik dan mental yang berimbang.

\section{DAFTAR PUSTAKA}

Ahmad Patusuri. 2012. Manajemen Pendidikan Jasmani dan Olahraga.Jakarta : Rineka Cipat.
Boyke Mulyana.2012. Ilmu Kesehatan Olahraga. Bnadung. PT. Remaja Rosda Karya.

H. JS. Sudarta. 2010. Pertumbuhan dan Perkembangan Peserta Didik (Olahraga Kesehatan). Bandung. Penerbit Alfabeta.

Cholik, Toha Mutohir. 2002. Gagasan-Gagasan Tentang Pendidikan Jasmani dan OLahraga.Penerbit : Unesa University Press.

Dini Rosdiani. 2012. Model Pembelajaran Langsung dalam Pendidikan Jasmani dan Kesehatan. Bandung. Penerbit Alfabeta.

Harsuki. 2012. Pengantar Manajemen OLahraga. Jakarta PT Raja Grafindo Persada.

E Mulyasa (2003) Kurikulum Berbasis Kompetensi. Konsep, Karakteristik, dan Implentasi. Bandung : Remaja Rosdakarya.

Mahendra. 2003. Hakekat Pendidikan Jasmani: PT. Gramedia Pustaka Utama.

Rusli Lutan .1996.Hakekat dan Karakteristik Pendidikan Jasmani dan Keschatan dalam Kurikuium D2 PGSD.Jakarta : Dirjen Depdikbud.

Roesdianto. 2012. Permainan dan Olahraga. Penerbit : Universitas Negeri Malang.

$$
\begin{array}{cr}
\text { Roesdianto.2012.Sejarah Olahraga dan } \\
\text { Pendidikan Jasmani.Penerbit } \\
\text { Universitas Negeri Malang. }
\end{array}
$$

Sugiono. 2012. Metode Penelitian Pendidikan : Pendekatan Kuantitatif, Kualitatif, dan R\&D. Bandung : Alfabeta. 